\title{
Surgical Management of Spinal Dysraphism: Five-year Experience in a Central Hospital
}

\author{
Banskota $\mathbf{N}^{1}$, Jha $\mathbf{R}^{2}$, Khadka $\mathbf{N}^{3}$, Sharma G $\mathrm{R}^{4}$, Bista $\mathrm{P}^{5}$, Kumar $\mathrm{P}^{6}$
}

\begin{abstract}
Introduction: Spinal dysraphism is a heterogeneous group of congenital spinal anomalies resulting from defective closure of the neural tube early in fetal life and anomalous development of the caudal cell mass. Meningomyelocele is common among Neural tube defects. Patients with myelomeningocele present with a spectrum of impairments, including primary functional deficits like are lower limb paralysis, sensory loss, bladderbowel dysfunction and cognitive dysfunction. Medical, surgical management and rehabilitation have helped patients with neural tube defects to participate and be productive in mainstream society. The aims of this study were to review the clinical presentation, surgical management and their outcome in the patient with spinal dysraphism. Materials and Methods: This is a retrospective study of Forty-one cases of spinal dysraphism managed during a period of five years from January 2008 to December 2012 in Department of Neurosurgery, National Academy of Medical Sciences (NAMS), Bir Hospital. Demographic profiles, clinical presentation of patients with spinal dysraphism, associated hydocephalus, surgical management and outcome were studied. Results: Out of total 41 cases studied, male patients outnumbered female with $58.5 \%$ to $41.5 \%$. Age ranged from 5 days to 29 years and mean age was 2.71 years whereas. Lump $(97 \%)$ and paraparesis $(88 \%)$ were frequent mode of presentation. Lumbar lesion (65\%) was commonest followed by lumbosacral (29\%). Hydrocephalus was present in $51 \%$ of cases and in $24 \%$ cases developed hydrocephalus later after repair. Total $75.6 \%$ of cases were treated with VP shunt. Conclusion: Spinal dysraphism is debilitating entity and management is challenging. Lump on back and weakness of limb are major factor for children and their parents seek medical service. Lesion in low back (lumbar and lumbosacral) were most common location. Besides repair, majority of them needed CSF diversion surgery for hydocephalus. Aim of surgical management was to prevent further deterioration, control of hydrocephalus or leak.
\end{abstract}

Key words: Spinal dysraphism, Hydrocephalus, Surgical management

\section{Introduction}

pinal dysraphism, or neural tube defect (NTD), is a broad term encompassing a heterogeneous group of congenital spinal
'Dr. Narendra Banskota, MBBS, MS, MCh Resident, ${ }^{2}$ Dr. Rajiv Jha MS, MCh, ${ }^{3}$ Dr. Nilam Khadka, Assistant Professor, ${ }^{4}$ Dr. Gopal Raman Sharma MBBS, MS, Associate Professor, ${ }^{5}$ Dr. Prakash Bista MBBS, MS, MCh, Associate Professor and Head of Department, ${ }^{6}$ Dr. Pawan Kumar, Professor, Department of Neurosurgery, National Academy of Medical Sciences (NAMS), Bir Hospital, Kathmandu, Nepal.

\author{
Address for correspondence \\ Dr. Narendra Banskota \\ Department of Neurosurgery \\ National Academy of Medical Sciences (NAMS) \\ Bir Hospital \\ Kathmandu, Nepal. \\ Tel: +977-8941487414 \\ E-mail: narendrabanskota@gmail.com
}

\section{How to cite}

Banskota N, Jha R, Khadka N, Sharma G R, Bista $P$, Kumar P. Surgical Management of Spinal Dysraphism: Five-year Experience in a Central Hospital. J Nepal Paediatr Soc 2014;34(1):34-38.

doi: http://dx.doi.org/10.3126/jnps.v34i1.9378

This work is licensed under a Creative Commons Attribution 3.0 License.

\section{(c) (i)}

anomalies that result from defective closure of the neural tube early in fetal life and anomalous development of the caudal cell mass ${ }^{1,2}$. The prevalence of NTDs varies widely between 1 and 10 per 1,000 births, depending on geographic region and ethnical grouping, making them one of the most frequent congenital malformations ${ }^{3}$. In Nepal, a demographic and health survey ${ }^{4}$ reported incidence of NTD is 47/10,000 live birth. Word "Spinal Dysraphism" was coined by B W Leichenstein in 1940. NTDs can be classified as "open" NTDs in which the neural tissue is exposed and "closed" NTDs with the neural tissue covered by tissue ${ }^{5,6}$. 
Patients with myelomeningocele present with a spectrum of impairments, including primary functional deficits like lower limb paralysis, sensory loss, bladderbowel dysfunction and cognitive dysfunction ${ }^{7}$. Patients with neural tube defects are participating and can be productive in mainstream society if proper treatment and care given to them. However, medical, surgical, and rehabilitation issues arise in the patient with myelomeningocele from birth through adulthood. The anatomic level of the myelomeningocele sac roughly correlates with the patient's neurologic, motor, and sensory deficits ${ }^{9}$. This condition is associated with several CNS malformation (Chiari II), cardiac anomalies, cleft lip and palate and genitourinary tract anomalies ${ }^{10}$.

Besides folic acid deficiency, etiology in most cases of myelomeningocele is multifactorial, involving genetic, racial, and environmental factors (e.g., teratogens). Intrauterine exposure to antiepileptic drugs, particularly valproate and carbamazepine, and to drugs to induce ovulation are identified risk factors ${ }^{11,12,13}$. Research in the 1980 s showed correction of folic acid deficiency as an effective means of primary and recurrent prevention ${ }^{14}$. A 2008 study estimated that fortification programs prevent about 22,000 cases, or $9 \%$ of the estimated folic acid-preventable spina bifida and anencephaly cases in United states ${ }^{15}$.

The aim of this study were to review the clinical profile, presentations of patients with spinal dysraphism in our region, surgical management, its' association with hydrocephalus and their outcome in the patient.

\section{Material and Methods}

This was a retrospective study of 41 cases of spinal dysraphism managed during period of five years from January 2008 to December 2012 in Department of Neurosurgery National Academy of Medical Sciences (NAMS), Bir Hospital. All meningomyelocele, meningocele from cervical to sacral region operated in this institute were included in this study. Spina bifida occulta, encephalocele and cases of tethered cord previously operated in other centres were excluded from the study. Demographic profiles, clinical presentation, surgical management, outcome of these cases were studied.

\section{Results}

Forty-one cases were studied. Mean age at presentation was 2.71 years with age ranging from 5 days to 29 years (Figure 1). Male and female patients were $58.5 \%$ and $41.5 \%$ respectively.
Table 1: Clinical presentation

\begin{tabular}{|l|c|}
\hline Clinical Manifestation & Frequency (\%) \\
\hline Lump & $40(97.5)$ \\
\hline Paraparesis & $36(87.8)$ \\
\hline Sphincter incontinence & $19(46.3)$ \\
\hline Cutaneous stigmata & $13(31.7)$ \\
\hline
\end{tabular}

Table 2: Skin Lesion

\begin{tabular}{|l|c|}
\hline Skin lesions & $\mathbf{n = 1 3}$ \\
\hline Lipoma & 6 \\
\hline Dermal sinus & 3 \\
\hline Hairy tuft & 2 \\
\hline Appendages & 1 \\
\hline Nevus & 1 \\
\hline
\end{tabular}

Table 3: Geographical distribution of patients (Region Wise) of Nepal

\begin{tabular}{|l|c|}
\hline \multicolumn{1}{|c|}{ Region } & $\mathbf{n = 4 1}$ \\
\hline Central & 24 \\
\hline Eastern & 7 \\
\hline Western & 6 \\
\hline Mid-western & 3 \\
\hline Far-western & 1 \\
\hline
\end{tabular}

Table 4: Location of dysraphism in Spine

\begin{tabular}{|l|c|}
\hline \multicolumn{1}{|c|}{ Location } & $\mathbf{n = 4 1}$ \\
\hline Cervical & 1 \\
\hline Thoracic & 1 \\
\hline Lumbar & 27 \\
\hline Lumbosacral & 12 \\
\hline
\end{tabular}

Table 5: Complications

\begin{tabular}{|c|c|}
\hline Complications & $\mathbf{n = 1 5}$ \\
\hline Hydrocephalus & 10 \\
\hline Wound infection & 2 \\
\hline CSF leak & 2 \\
\hline Shunt infection & 1 \\
\hline
\end{tabular}

Ventriculoperitoneal (VP) Shunt was required in $31(75 \%)$ cases, 21 (51\%) cases had concurrent hydrocephalus and 10 (24\%) cases developed hydrocephalus after repair. In $80 \%$ cases primary closure was possible. Rest needed reinforcement with paraspinous fascia. CSF sent for routine investigation after each VP shunt found to be normal, so infection was not the cause for hydrocephalus before or after repair of $\mathrm{MMC}$.

Eight cases where subarachnoid lumbar drain was kept per operatively, two needed VP shunting. Lumbar 
drain prevented wound site CSF leak. Two cases with CSF leak was managed with primary closure of leak, intravenous antibiotic and later they were shunted
(VP Shunt) as they developed hydrocephalus. One developed shunt infection which was managed initially with external ventricular drain and later VP Shunt.

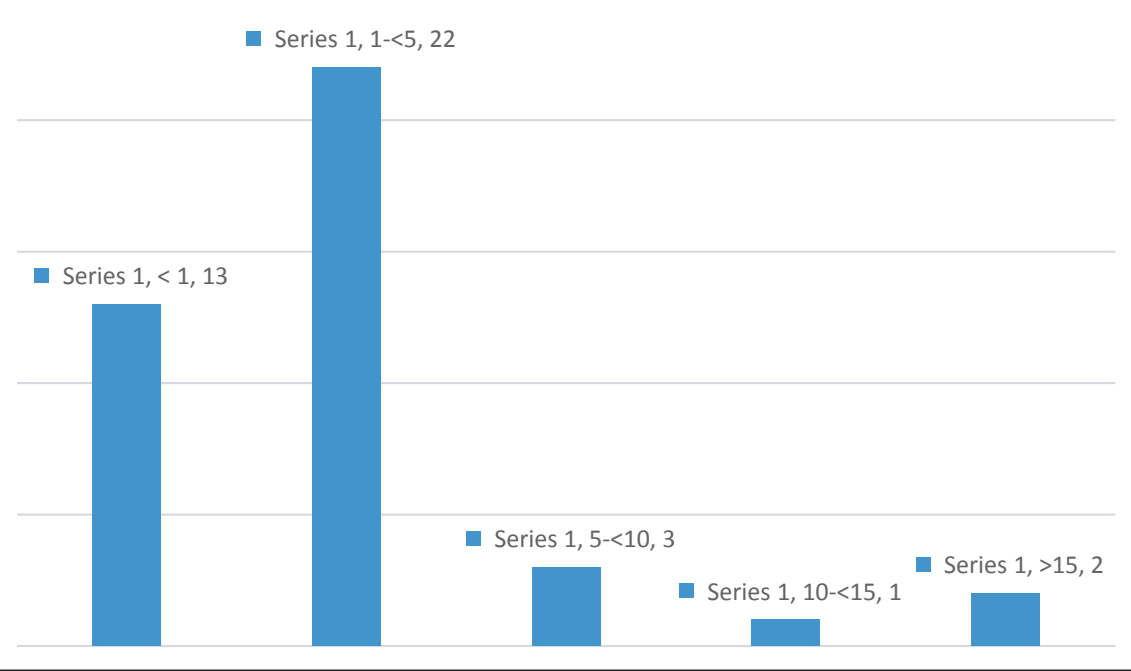

Fig 1: Age wise distribution of patients

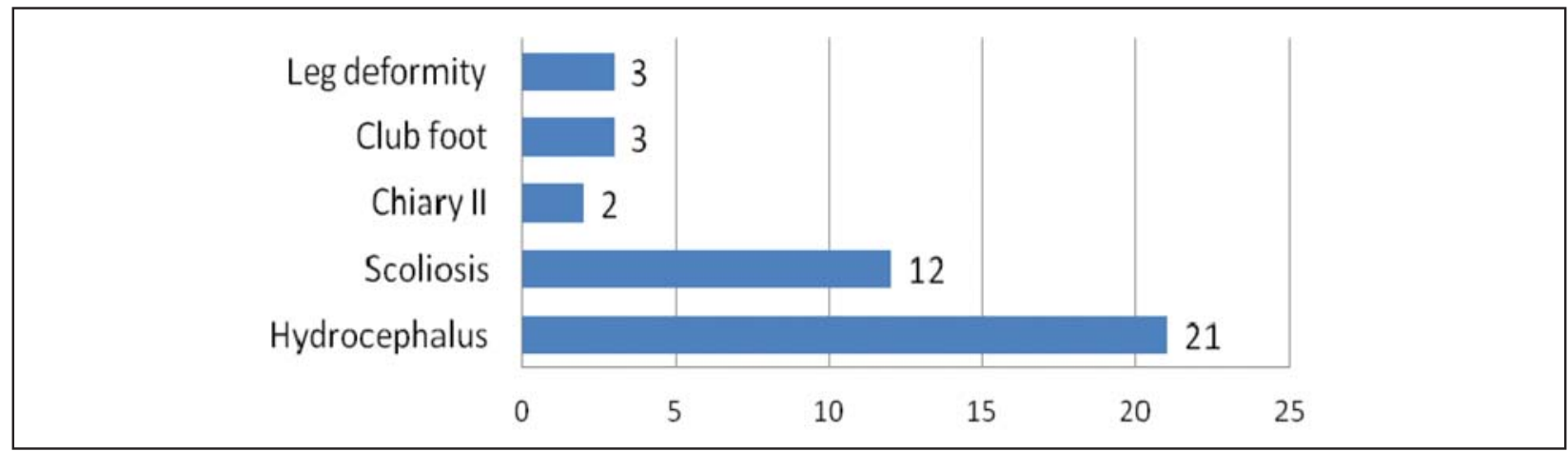

Fig 2: Congenital Anomalies associated with spinal dysraphism

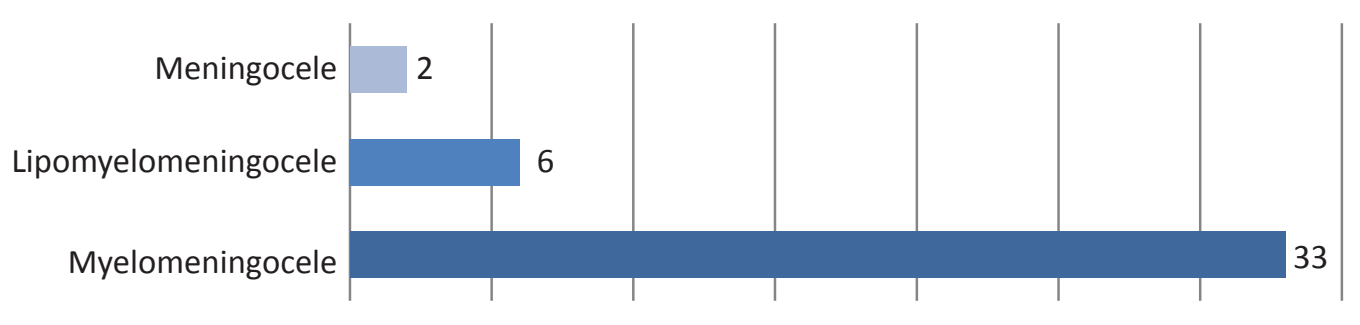

Fig 3: Histopathology of spinal dysraphism

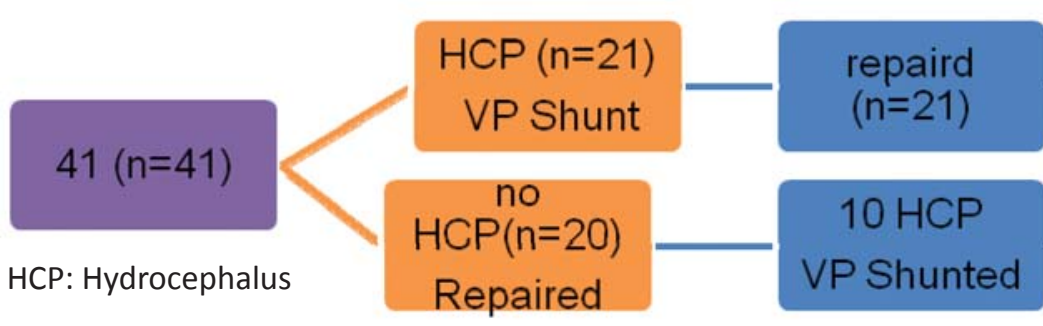

Fig 4: Chart showing management of patients 


\section{Discussion}

The incidence of spinal dysraphism is approximately 1 per 1,000 live birth ${ }^{16}$. This declined 50\% between 1970 and 1989 (0.6-1.3 cases per 1000 live births) in the United States. ${ }^{17}$ Despite aggressive medical care, $10-15 \%$ of these children die prior to reaching the first grade. However, most children with isolated myelomeningocele (without major anomalies of other organs) survive to adulthood, and life expectancy is nearly normal ${ }^{18}$. The most common presentation of a closed NTD is an obvious abnormality along the spine such as a fluid-filled cystic mass, area of hypopigmentation or hyperpigmentation, cutis aplasia, congenital dermal sinus, capillary telangiectasia/ hemangioma, hairy patch (hypertrichosis), skin appendages, or asymmetrical gluteal cleft ${ }^{19}$. The birth prevalence rate of myelomeningocele was slightly higher in females than in males (1.2:1), based on data from state and national surveillance systems from $1983-1990^{10}$. In this study males outnumbered female with ratio of 1.4:1.

In a fetal ultrasonographic study done to detect congenital anomalies, defects were located in lumobsacral region in $90 \%$ of cases, in thoracic region $6-8 \%$, and in cervical vertebrae $2-4 \%{ }^{17}$. In a study of north India, ${ }^{20}$ Out of 155 cases of spinal dysraphism, 119 had open spina bifida [meningomyelocele (MMC) in 113 (72\%), meningocele in $3(2 \%)$ and myelocystocele in $3(2 \%)$ ] and 36 had occult spina bifida [split cord malformation (SCM) without overt MMC sac (pure SCM) in 29 (19\%) and midline dermal sinus in 7 (4.5\%)]. In a series, ${ }^{21}$ most common location was lumbosacral (44\%) followed by dorsolumbar (32\%). In this study, commonest site (Table 4) was lumbar (66\%) and Lumbosacral regions (29\%). In about $90 \%$ of the children with myelomeningocele, hydrocephalus also occurs because the displaced cerebellum interferes with the normal flow of cerebrospinal fluid, causing an excess of the fluid to accumulate ${ }^{22}$. In this study total of $31(75 \%)$ cases needed VP shunting (Figure 4). Among them 10 (24\%) developed hydrocephalus after repair. In 8 cases, lumbar drain was kept in subarachnoid space peroperatively and kept for 5-7 days. This helped in prevention of CSF leak. In this study, VP shunt was performed for cases with HCP in emergency and repair done as elective. Emergency repair is the protocol for ruptured meningomyelocele to prevent meningitis and hypotention.

\section{Future perspective}

In Europe, open fetal surgery for spina bifida was introduced in 2003 by the Polish paediatric surgeon Janusz Bohosiewicz in Katowice. Through the end of
2011, more than 40 fetuses with spina bifida were operated at that center ${ }^{23}$. Experience on endoscopic fetal surgery was presented at various national and international meetings but its clinical introduction was affected by technical difficulties and a number of adverse fetal outcomes ${ }^{24}$. Such advanced foetal surgery facilities are yet to be set in our region. As a part of preventive program in rural Nepal, Micronutrient Initiative (MI) began working with village millers to help them add essential vitamins and minerals to the cereal flour they produce since $2007^{25}$.

\section{Conclusions}

Spinal dysraphism is debilitating entity and management is challenging. Lump on back and weakness of limb are major factor for children and their parents seek medical service. Lesions in low back (lumbar and lumbosacral) were most common location. Besides repair, majority of them needed CSF diversion surgery. Aim of surgical management was to prevent further deterioration and control of hydrocephalus or leak.

Acknowledgement: We sincerely are thankful to all faculties, nurses of Department of Neurosurgery, and staffs of record section of NAMS, Bir hospital and studied patients and their parents for completion of this study.

Funding: Nil

Conflict of Interest: None

Permission from IRB: Yes

\section{References}

1. Dias MS, Li V. Pediatric neurosurgical disease. Pediatr Clin North Am Dec 1998; 45(6):1539-78.

2. McComb JG. Spinal and cranial neural tube defects. Semin Pediatr Neurol 1997;4(3):156-66.

3. Hibbard B.M., Hibbard E.D., Jeffcoate T.N. Folic acid and reproduction. Acta Obstet Gynecol Scand 1965;44:375-400.

4. Demographic and Health Survey 2011, Calculated from March of Dimes statistics, 20-March-2012. Available from: http://www.ffinetwork.org/ country_profiles/country.php?record=149

5. Northrup H, Volcik K.A. Spina bifida and other neural tube defects. Curr Probl Pediatr 2000;30:313-332.

6. Sadler T.W. Embryology of neural tube development. Am J Med Genet C Semin Med Genet 2005;135C:2-8. 
7. Vinck A, Nijhuis-van der Sanden MW, Roeleveld NJ. Motor profile and cognitive functioning in children with spina bifida. Eur J Paediatr Neurol 2010;14(1):86-92.

8. Thompson DN. Postnatal management and outcome for neural tube defects including spina bifida and encephalocoeles. Prenat Diagn 2009;29(4):412-9.

9. Fletcher JM, Copeland K, Frederick JA, Spinal lesion level in spina bifida: a source of neural and cognitive heterogeneity. J Neurosurg 2005; 102(3 Suppl):268-79.

10. Spina Bifida [Internet]. Mark R Foster: Medescape Bifida, c2012-[Cited 2013 Nov 29]. Available from: http://emedicine.medscape.com/article/311113overview

11. Nickel RE, Pillers DA, Velo-cardio-facial syndrome and DiGeorge sequence with meningomyelocele and deletions of the 22q11 region. Am J Med Genet 1994;52(4):445-9.

12. Wu YW, Croen LA, Henning L. Potential association between infertility and spinal neural tube defects in offspring. Birth Defects Res A Clin Mol Teratol 2006;76(10):718-22.

13. Canfield MA, Ramadhani TA, Shaw GM. Anencephaly and spina bifida among Hispanics: maternal, sociodemographic, and acculturation factors in the National Birth Defects Prevention Study. Birth Defects Res A Clin Mol Teratol 2009;85(7):637-46.

14. Milunsky A, Jick $H$, Jick SS, Bruell CL, MacLaughlin DS, Rothman KJ et al. Multivitamin/folic acid supplementation in early pregnancy reduces the prevalence of neural tube defects. JAMA 1989;262(20):2847-52.

15. Centers for Disease Control and Prevention. Spina bifida and anencephaly before and after folic acid mandate--United States, 1995-1996 and 19992000. MMWR Morb Mortal Wkly Rep. May 72004 ; 53(17):362-5.

16. Bell KN, Oakley GP Jr. Update on prevention of folic acid-preventable spina bifida and anencephaly. Birth Defects Res A Clin Mol Teratol 2009;85(1):102-7.

17. Entezami M, Albig M, Gasiorek. Spina Bifida Aperta, (Myelo-) Meningocele. In: Wiens A, Becker $\mathrm{R}$ (eds) ultrasound Diagnosis of Fetal Anomalies, Stuttgart, Georg Thieme Verlag, 2004: 51-56.

18. Marks JD, Khoshnood B. Epidemiology of common neurosurgical diseases in the neonate. Neurosurg Clin N Am 1998;9(1):63-72.

19. Mattsson S, Gladh G. Children with meningomyelocele becomeadults! Lakartidningen. 2005;102(37):2566-570.

20. Drolet B. Birthmarks to worry about. Cutaneous markers of dysraphism. Dermatol Clin 1998;16(3):447-53.

21. Kumar R, Singh SN, Spinal dysraphism: trends in northern India: Pediatr Neurosurg 2003; 38(3):133-45.

22. Arun Kumar, Veena Diagnostic Radiology Paediatric Imaging 3rd ed, New Delhi: Jaypee; 2011. p337.

23. Chiari Malformation Fact Sheet [Internet]: National Institute of Neurological Disorders and Stroke (NINDS). [Cited 2011-10-23]. Available from: http://www.ninds.nih.gov/disorders/chiari/ detail_chiari.htm\#186143087

24. Bohosiewicz J, Koszutski T, Kowalik J, Olejek A, Zamłyński J, Ziomek G. Fetal repair of myelomeningocele in human fetuses. Experience related with 33 cases. Arch Perinatal Med 2011;17(2):81-84.

25. Degenhardt J, Schürg R, Kawecki A, "Maternal outcome after minimally-invasive fetoscopic surgery for spina bifida. The Giessen experience 2010-2012. Ultrasound Obstet Gynecol 2012;40(Suppl. 1) 9.

26. Micronutrient Fortification of Cereal Flours at Water Mills in Rural Nepal. The Micronutrient Initiative, annual report 2011-2012 [cited on 18dec 2013] available from: http://www.micronutrient. org/English/View.asp?x=727. 